\section{THE DECLINE OF SOCIALIST REALISM IN POST-1975 VIETNAMESE LITERATURE*}

\section{Montira Rato**}

\begin{abstract}
In Vietnam, Socialist Realism served as a tool for the party and the state to control art and literature. Its emphasis on the utilitarian function of literature and collectivism is a good explanation for why it flourished in Socialist countries, including Vietnam. However, Socialist Realism was found unsuitable for the development of Vietnamese literature in the post-1975 period. This study tries to examine how Socialist Realism was adopted and adapted in Vietnam, and why it was challenged in the post-war period.
\end{abstract}

\section{Introduction}

In Vietnam, unsolved literary tension was caused by the literary theory called Socialist Realism, which had been established and sanctified for over thirty years. The problems of literary activity in Vietnam, resembling what happened in other socialist societies, stemmed from the

\footnotetext{
* This paper is part of the two-year research project on Dynamics and Changes of Post1975 Vietnamese Literature, which is financially supported by The Thailand Research Fund (TRF) and The Commission on Higher Education, Ministry of Education, Thailand.

Assistant Professor in Vietnamese, Faculty of Arts, Chulalongkorn University, Bangkok, Thailand.
}

fact that state authorities attempted to control artistic and literary creativity under the theory of Socialist Realism. Due to the changes in political climate after the Vietnam War, while ended in 1975, a group of Vietnamese intellectuals and writers tried to separate literature from state control and challenge the Socialist Realist style of writing.

The following parts of this study will try to answer what Socialist Realism is, and how it was established and developed in Vietnam before it was challenged in the post-war period. This will be followed by a discussion of well-known literary works to illustrate how post-war writers tried to remove the elements of Socialist Realism from literary pages. However, the discussion will focus only on the novels and short stories written during the period between 1975 and 1986, which can be regarded as the transitional period from wartime to Renovation (Đổi Mới) literature. ${ }^{1}$ Due to the Renovation policy launched in late 1986, writers and critics openly moved towards the new literature, a milestone which unofficially marked an end to Socialist Realism in Vietnamese literature. This study will also show that the development of Renovation literature

\footnotetext{
${ }^{1}$ The term "renovation" refers to the economic and political reforms (Đổi Mới), which began in 1986 at the sixth Party Congress. Nguyễn Văn Linh, General Secretary of the Communist Party in the mid-1980s, tried to move away from centralized control towards a market economy in order to rescue the country from economic and political crisis. The Renovation policy dramatically affected literary and cultural activity in Vietnam. Vietnamese writers took this opportunity to explore a wider range of new themes, to experiment with new styles of writing and delineate objective truth. They also challenged readers to rethink and reinterpret what happened in the past with a new perspective.
} 
was not sudden and, in fact, was a result of the long efforts of those in the literary domain; namely, writers, critics and scholars. Thus, the effort to move away from the guidance of the Socialist Realist theory during the period of 1975-1986 can be seen as an attempt to pave the way for Renovation literature starting in the late 1980s.

\section{What is Socialist Realism?}

It is not easy to define Socialist Realism, but it is a literary style of writing that played an important role in the literary production of Socialist countries in the $20^{\text {th }}$ century, Vietnam included. The term 'Socialist Realism' emerged in the early 1930s. According to Brown, it was coined in 1932 and attributed to Stalin, but nobody knows the exact origin of this literary term (Brown 1982: 15). A discussion of Socialist Realism was officially made in August 1934 at the First All-Union Congress of Soviet Writers presided over by Maxim Gorky. The speeches delivered by leading Soviet writers at the congress implied that the government demanded artists and writers to take part in the building of Socialist society. In order to respond to government policy, writers needed to find a new literary technique and form to portray the new life, new Socialist men and new society. Finally, Socialist Realism was chosen as the official style of writing for all writers.

Although Socialist Realism is regarded as a strict style of writing, it was a reaction to an even stricter literary form of the regiment literature of the First Five-Year Plan by the RAPP (Association of Soviet
Proletarian Writers) ${ }^{2}$ under which 'the writers became a professional worker with definite duties determined by political, social, and economic considerations' (Borland, 1950: 1). The RAPP's Rabkor (industrial literature) promoted a closer relationship between writers and workers and required authors to produce mainly industrial and political literature.

Also at the congress, Andrey Zhdanov, the Secretary of the Central Committee of the Communist Party of Soviet Union (CPSU), promoted the role of writers as 'the engineers of human souls', an idea which was introduced by Stalin. He also encouraged Soviet writers to use Socialist Realism as a guideline for writing. Maxim Gorky, whose well-known novel Mother was regarded as a remarkable example of Socialist Realist work, exerted his effort to strengthen the role of writers in the Socialist state and tried to give a definition to Socialist Realism. Apart from these two high-ranking Soviet writers, other eminent writers and poets such as Karl Radek and Nikolai Bhukarin, also paid considerable attention to the discussion of Socialist Realism.

Nevertheless, Socialist Realism is a problematic term. That is to say, there is no clarification of the term. It is rather an attempt to reformulate what is already present or what has already been said (See Robin 1977: 39). For Gorky, Socialist Realism was a pseudonym for 'revolutionary romanticism' (Struve 1946:

\footnotetext{
${ }^{2}$ The RAPP (Association of Soviet Proletarian Writers) was formed in 1926. Later, the CPSU (the Communist Party of Soviet Union) ordered RAPP to dissolve on April 23, 1932, and a few months later the first single and official association of Soviet writers was founded under the name 'the Union of Soviet Writers.'
} 
244). Even though it is quite difficult to find an exact definition of Socialist Realism, the main characteristics of this literary style of writing can be summarized from a discussion at the Soviet Writers' Congress 1934 as follows: AntiPessimism, Anti-Individualism, Objective Truth or Specific Truth, and Typification of Heroes and Myth Making (See Scott 1977). More importantly, Socialist Realism is closely connected to the development of Socialism. As Radek's explains:

Socialist Realism means not only knowing reality as it is, but knowing where it is moving. It is moving towards socialism, it is moving towards the victory of the international proletariat. And a work of art created by a socialist realist is one which shows where that conflict of contradictions is leading which the artists had seen in life and reflected in his work.

(Scott 1977: 157)

\section{Literary transformation in Vietnam}

After the August Revolution and the declaration of independence by Hồ Chí Minh in September $1945^{3}$, there was no more debate between 'art for art's sake' (nghệ thuật vi nghệ thuật) and 'art for life' (nghệ thuật vi nhân sinh), the literary debate which prevailed in Vietnamese society during the 1930s (See Hue Tam Ho Tai 1982: 63-83). This is because the writers began, after the Communists took

${ }^{3}$ In 1945, the Vietnamese Communists defeated the French troops in Hanoi on August 19, in Huế on August 23 and in Saigon on August 25. control from the French, to believe that the concept of collectivism could provide a solution for the survival of the country, and literature should take part in the struggle for national independence. Moreover, the return of French troops in 1946 made Vietnamese intellectuals, writers and artists, whether or not they regarded themselves as Communists, realize that the revolutionary task was their first priority. In North Vietnam, 'cái tôi' or the 'I / Individuality' was not allowed in literature, and was gradually replaced by 'cái $t a$ ' or the ' $W e$ l Collectivism.' It was assumed that only 'cái ta' could lead Vietnam towards victory against foreign troops and was beneficial for the development of Socialism, whereas 'cái tôi' was regarded as a main obstacle to the progress of the nation. As seen in the critical writing of Văn Tân and Nguyễn Hồng Phong, intellectuals in general, and writers in particular, were required to transform their 'bourgeois self' into the 'proletariat self'(Văn Tân và Nguyễn Hồng Phong 1957: 54-55).

Hồ Chí Minh severely criticized individualism in the article 'Nâng cao đạo đức cách mạng, Sạch chủ nghĩa cá nhân' (To Increase Morality of the Revolution, To Wipe out Individualism). He pointed out that the morality of the revolution was 'tập thể' (collectivism), 'đoàn kết' (unity), 'tồ chúc' (organization) and 'kỷ luật' (discipline). Individualism needed to be eliminated because it was disadvantageous to the revolution. In his writing, he asked Vietnamese people to keep in mind 'minh vì moi nguời' (one for all) in order for Vietnam to achieve victory (Hồ Chí Minh 
1996:438-439). ${ }^{4}$ Consequently, Vietnamese writers had to participate in political affairs and their works were used as propaganda and as part of the mass mobilization. They were not allowed to write about personal dreams or individual concerns, but were required instead to stimulate (cổ vũ) people to make a greater effort and contribution to the survival of the nation. The essay "Nhận Đường" (Recognise the Path) by the famous writer, Nguyễn Đình Thi, can be regarded as a manifesto for the writers of this period. Nguyễn Đình Thi pointed out that the responsibility of writers to the fatherland was unavoidable and that it was necessary for literature to unite people and strengthen their souls in so that they could overcome the odds and win the battle. As he wrote:

...The sound of the war exploded. Our direction is very clear: everything for the struggle, everything for the nation...we will turn everything to the flag of the nation; to write, to draw pictures, to compose music, to fight on a literary front. Every creation is a bullet shot at the head of the enemy.

(Nguyễn Đình Thi 1998: 191)

This attempt to turn literature into a political tool reflects the principles of 'party literature' laid down by Lenin. That is:

Literature must become part of the common cause of the proletariat, "a $\operatorname{cog}$ and a screw" of one

\footnotetext{
${ }^{4}$ Hồ Chí Minh, The article was written for the 39th anniversary of the foundation of the Communist Party on February 3, 1969.

${ }^{5}$ Nguyễn Đình Thi wrote this essay in 1947.
}

single great Social-Democratic mechanism set in motion by the entire politically-conscious vanguard of the entire working class. Literature must become a component of organized, planned and integrated Social-Democratic Party work.

(Lenin 1970: 23)

As in other Communist states, the Communist government in Vietnam tried to control literary production and intellectual life, as seen in Vietnamese Cultural Theses (Đề Cương Văn Hoá Việt Nam) (Trường Chinh 1960: 182-187) published in 1943, but more widely known after 1945, by the Communist leader, Trường Chinh (pseudonym of Đặng Xuân $\mathrm{Khu}$ ). In it, three principles are outlined for writers and cultural laborers to follow. The first principle is 'dân tộc hoá,' to nationalize and fight against the influence of Colonial culture, either French or Chinese. The second is 'đại chúng hoa', or popularization, which requires cultural activities to be connected to the interests of people. The final principle is 'khoa hoc hoá' or to 'make scientific,' which relates to logical thinking and a concern for grammar and sentence structure.

It should be noted that, in terms of practice, Vietnam is politically and culturally influenced by the Chinese model and Maoism. It is obvious that the 1948 report on 'Marxism and Vietnamese Culture' by Trường Chinh shared similarities with Mao Tse-Tung's 'Talks on Literature and Art' at Yenan in May 1942. The guidelines launched by Mao Tse-Tung and other famous Chinese writers and critics reveal that the Chinese government tried not only to control literature and art but also to subordinate literature and art to politics. Since the 
1950s, the influence of the Chinese pattern on Vietnamese literary policy became more visible (see Mao Tse-Tung 1967).

\section{Socialist Realism in Vietnamese literature}

Trường Chinh played a vital role in drawing cultural outlines and establishing a new idea about culture, art and literature, in particular in Marxism and Vietnamese Culture (Chủ Nghĩa Mác và Văn Hoá Việt Nam), published in 1948. The main concern of this work was to explore theories of culture, the development of Vietnamese culture and other issues related to literature and art. Trường Chinh officially recommended in Marxism and Vietnamese Culture Socialist Realism as a literary style for Vietnamese writers. As he put it:

All that has been said leads to this conclusion: the stand of the most revolutionary culture in the world and in our country in our day is as follows: The working class constitutes the social basis. National independence, peoples' democracy and socialism are the political basis. Dialectical materialism and historical materialism form the ideological basis. Socialist Realism should be treated as the artistic basis. [sic]

(Trường Chinh 1994: 220-221)

Then, he tried to define the terms. According to Trường Chinh's explanation, Socialist Realism is:

a method of artistic creation which portrays the truth in a society evolving towards socialism according to objective laws. Out of objective reality we must spotlight "the typical features in typical situations" and reveal the inexorable motive force driving society forward and the objective tendency of the progress of evolution.

(Trường Chinh 1994: 229)

Trường Chinh stressed that Socialist Realism focuses on reflecting truth, but he also warned writers to be aware of what kind of truth should be included or left out in their works. As he explained:

There are objective truths which are unfavorable to us. For example, shall we report a battle we have lost truthfully? We can, of course, depict a lost battle, but in doing so, we must see to it that people realize how heroically our combatants accepted sacrifices, why the battle was lost... it should be borne in mind that there are truths worth mentioning, but there are also truths which are better left unmentioned, at least temporarily, and if mentioned at all, the question is where and how they should be revealed.

(Trường Chinh 1994: 270)

From that point, Socialist Realism became the official style of writing for Vietnamese writers. Its elements, such as "objective" truth, optimism or mythmaking, became key words for literary production and criticism in North Vietnam. However, in the post-1975 period, this literary doctrine began to be questioned by writers and critics. 


\section{The decline of Socialist Realism in post-war literature}

The year 1975 has great meaning in Vietnamese history. The victory of North Vietnam over the United States Army and the government of South Vietnam ended the long traumatic years of war, and reunified the two parts of the country. Throughout the long struggle, from the French resistance, the building of a Socialist country to the Vietnam War, Vietnamese literature also had to sacrifice its aesthetic values and serve politics. Soon after the war ended, Vietnamese writers felt that their duty as citizens was completed and they no longer needed to sacrifice the literary merit of their works for the sovereignty of the nation. The end of the war in 1975 marked a new period of literary development in Vietnam because the transformation from war to peace not only allowed Vietnam to develop economically and socially, but also to move towards a new page of Vietnamese history, with a new generation and new perceptions. Likewise, the effort to disengage literature from politics began to take shape in the post-1975 period and it is clear that the Socialist Realist style of writing was challenged, if not overthrown.

The polemics on new literature started with the idea of realism in literature. This topic was brought to public attention in the article "Viết về Chiến Tranh" (Writing about War) [1978] by the famous soldierwriter Nguyễn Minh Châu. This article widely initiated an awareness about how the war was represented and narrated in Vietnamese literature. In this well-known article, Nguyễn Minh Châu commented that writing about war failed to impress readers because writers paid more attention to historical events than to depicting the psychological state of those who had undergone the war. Moreover, the portrayals of the war were not realistic. The Vietnamese soldiers were characterised as extremely good whereas the enemies were totally bad. As he asserted, "reality" in war literature was a 'wishful reality' rather than 'actual reality'. (Nguyễn Minh Châu 1978: 110115) Back in 1971, Nguyễn Minh Châu had discussed the weak points of using epic as a genre for writing about war and following Socialist Realism, literary guidelines laid down by the party. He also made an observation that Vietnamese literature was predictable because it was constructed with the same content and same style of writing. As he put it:

The first time we read, it is very interesting. The second time we read, it becomes less interesting. The third time we read, it is rather boring. Until the fourth time, we get annoyed because authors should not write in the way that makes readers feel that literature itself is 'taking refuge.'

(Nguyễn Minh Châu 1994: 28) ${ }^{6}$

The discussion on the role of literature in the post-war period became more controversial when Hoàng Ngọc Hiến, a well-known literary critic and scholar, published the article "Về môt đặc điểm của văn học và nghệ thuật ở ta trong giai đoạn vì̀a qua" (On a Main Characteristic of Our Literature and Art in the Period just Passed) [1979] (Hoàng Ngọc Hiến 1979: 2-3). In this influential article, the author called pre-1975 literature Văn Học Phải $Đ a o$ or 'doctrinal literature,' which is a kind of literature that has to behave itself and conform to political doctrine. Plot and

\footnotetext{
${ }^{6}$ Nguyễn Minh Châu, This article is first published in Văn Nghệ Quân Đội, no. 3, 1971.
} 
characterization illustrated doctrine. Hoàng Ngọc Hiến also commented, similar to Nguyễn Minh Châu's observation, that there was an overlap between what really exists and what should be. It seemed to him that writers tended to present what should be and failed to honestly write about what actually existed in reality. Hoàng Ngọc Hiến implied that doctrinal literature was a result of the state's effort to create a single and unified literature under the frame of Socialist Realism, a style of writing which eventually became a ready-made formula for writers. That is why the same storyline, stereotyped characters and conflicts are often found the pre-1975 literature. However, in 1979 Vietnam had to endure a war with Cambodia and China. It was probably not the right time for Vietnamese literature to move away from the party line. Although Hoàng Ngọc Hiến's writing was widely discussed by scholars and critics, it was not approved by hardliners.

It can be noticed from the criticism directed against Hoàng Ngọc Hiến that most Vietnamese critics regarded literature as a part of history. If one commented that 1945-1975 literature was poor, then he or she also denied the great and heroic history of this period. This is because Vietnamese literature developed along with historical and political changes. For some critics, there could not be poor literature in the great and victorious period of Vietnamese history.

Socialist Realism remained Vietnam's official literary theory in the post-war period, but in practice it had clearly lost its popularity since the early 1970 s as it is often seen in the poems of young soldierpoets before it is more visible in novels and short stories written in the late 1970s. These young poets, like Nguyễn Duy,
Xuân Quỳnh and Thanh Thảo, took part in the war themselves and wrote what they saw from the battlefields: blood, wounds and death. This is different from poems by older poets who poeticized and idealized the war. For instance, the young poets found that it was inevitable to join the war, but they began to be skeptical and could not see, during hours of violent death, the beauty and heroism of the war expressed in the works of the older generation.

In the late $1970 \mathrm{~s}$, stories about the war also began to be presented in a new style of writing by soldier-writers, notably Thái Bá Lợi with his novel called Ho Cùng Thời với Nhũng $A i$ (They Live at the Same Time With Many People) [1980], Nguyễn Trí Huân with his work, Năm 75 Họ đã Sống nhu thế (The Year 1975 They Lived like That) [1979], and Nguyễn Trong Oánh with his novel, Đất Trắng (The White Earth) [1979]. These authors began to reveal another side of the war, such as failure, fear and death. For example, in the novel Đất Trắng (The White Earth), Nguyễn Trong Oánh reveals the failure of Vietnamese troops in 1968, when a large mobilization of the masses took place as well as recruitment of soldiers, in order to liberate the South. The result was many civilian and military deaths, a fact that became distorted by certain writers. Some writers even referred to this abortive attack as a victory because a typical Socialist Realist work should not contain such negativity. Although the novel Đất Trắng (The White Earth) was not as successful as stories about war written in the later period, such as Nổi Buồn Chiến Tranh (The Sorrow of War) by Bảo Ninh, it was an early attempt to unfold the true facets of the war.

As Nguyễn Minh Châu mentioned elsewhere, the wartime literature 
concentrates on representing positive aspects of life and the promising future of Socialism. During wartime, it is generally believed that heroism and optimism are advantageous to the mobilization of the masses. However, writers in the post-war era realized that they were no longer able to portray life in the same way as they had done in the previous period. Literature began to adapt itself to life after war, which is different from life in the wartime period. Daily activities, which were affected and interrupted during the war, began to resume normally in the post-war period. If the main concern of people in the wartime period was the survival of the nation, people in the post-war time were worried and disturbed by political disillusion and economic hardship. Nguyễn Minh Châu further commented that deification of characters in literature makes readers bored. Instead, characters should be portrayed as ordinary human beings. In fact, it is those ordinary people that took part in the war, fought against foreign troops and created history. For this reason, they should have the right to appear in the pages of a literary work (Nguyễn Minh Châu 1994: 269-281). ${ }^{7}$

Most successful works since the early 1980s contain elements not acceptable to the standard of Socialist Realism, such as individualism, anti-heroism and pessimism. Examples are Nguyễn Khải's novels such as Cha và Con và... (Father and Child and...) [1979], and Gặp Gõ Cuối Năm (Meeting at the end of the Year) [1982], Nguyễn Minh Châu's collection of short stories, such as Người Đàn Bà trên Chuyến Tàu Tóc Hành (A Woman on an Express Train) [1982], Ma Văn Kháng's successful works like Múa Mùa Hạ

\footnotetext{
${ }^{7}$ Nguyễn Minh Châu, The article was first published in Văn Nghệ Quân Đội, no. 1, 1984.
}

(Summer Rain) [1982] and Mùa Lá Rụng trong Vươn (The Season of Leaves Falling in the Garden) [1985], and Vú Tú Nam' s short story titled Sống với Thời Gian Hai Chiều (Living in Two Sides of Time) [1983]. Therefore, by the late 1980s, the majority of writers could no longer call themselves Socialist Realist writers.

On August 25, 1989, a discussion about the direction and future of Socialist Realism was officially held at the Institute of Literature in Hanoi. The talk was mainly about whether or not Socialist Realism should be considered as the official style of writing. However, the majority of writers, literary critics and scholars who attended the meeting hesitated to make a final decision. Although a few conservative scholars suggested at the meeting that writers should continue writing in the Socialist Realist form, this literary style of writing was less supported by many scholars and critics. $^{8}$ The prominent scholar Hoàng Ngọc Hiến even wanted it to be abolished, as he asserted:

Socialist Realism is a fake concept that has caused troubles for writers and artists, including scholars and authorities in the literary field, for a long time. At the beginning, it was just a banner, but then people turned it into a subject of study, elaborated it, ascribed to it a style of writing, and made it so powerful. The argument (on Socialist Realism) is useless (Hoàng Ngọc Hiến cited in Văn Nghê). ${ }^{9}$

\footnotetext{
${ }^{8}$ The report of the conference was published in Tạp Chí Văn Học, no.5, 1989. Pp. 8-27.

${ }^{9}$ Văn Nghệ newspaper (5-3-1988), p.2.
} 
Needless to say, this literary style of writing was no longer followed in practice, though it was strongly defended in theory. The decline of the Socialist Realist style of writing in post-war literature allowed writers to portray life with a different style of writing. Writers began to reveal a negative side of society rather than focus only on 'positive truth.' The late 1980s, with the more liberal atmosphere of the renovation policy since 1986, may have marked the end of Socialist Realism in Vietnam. However, one cannot overlook the attempt to remove the influence of this literary doctrine from the Vietnamese literary sphere since the end of the war in 1975. The following part of the study will discuss how literary works written between 1975 and 1986 are different from the so-called Socialist Realist literature of the wartime period.

\section{Literature for everyday life}

It can be noticed that post-1975 literature paid more attention to everyday life issues, which is in contrast to the Socialist Realist literature focusing on political and historical events. For example, the short story Sống với Thời Gian Hai Chiều (Living in Two Sides of Time) [1983] by Vũ Tú Năm shows that a person also has to pay attention to personal life apart from fulfilling his or her duty as a citizen. The story reveals how people live in difficulty in a transitional period, from wartime to peace. In the short story, An, a veteran who spent most of his time at the front, returns to his family when the war is over. On a visit to his relatives in his home village, he learns that living a civilian life is much more difficult than fighting at the front. Relationships between people are also complex. He has to accept that he does not know how to be a good husband and father. It is even more difficult when he learns that Ngàn, his former lover, is still loyal to him and regards him as her husband. Ngàn told Bình, her adopted daughter, that An was her father. Then, when Bình had her own son, she told him that An was his grandfather. Finally, An decides to accept Bình and her son although they have no blood relation. As shown in the complex relation between An, Ngàn and Bình, human life is full of twists and turns. It is painful for Ngàn that she could not marry An. It is not easy for Bình to learn that An is not her father. It is very difficult for An to discover that there are women who claim to be his wife and daughter. As shown in this short story, relationships between people are also fragile. If one is not careful enough, one can unintentionally hurt innocent people.

As pointed out in Vũ Tú Nam's short story, the duty of human beings is more than being a good citizen, joining the war or defending the nation. As seen from An, he is not only a soldier but also a father and husband. Although the war is over and his responsibility to the country has finished, he still has to complete responsibilities to his own family and other people with whom he is involved. From the story, it seems the author attempts to warn his generation and readers who lived through the war that life is not simple. As An says: 'life is like that! we have to follow its law, we are drawn into life whether we like it or not. Sometimes, it is really funny (Vũ Tú Nam 1985: 411).'

The change of topic from war to daily life problems is remarkably shown in Mùa Lá Rung trong Vuờn (The Season of Leaves Falling in the Garden) [1985] by Ma Văn Kháng. In this novel, there is no heroism, optimism or historical event often found in literary works written in the pre-1975 
period. The story is mainly based on family affairs and everyday life problems that ordinary people have to endure, such as how to earn a living, the decline of the family system and the deterioration of morality in post-war society. This novel also reveals the complicated relationship between human beings, family and society. Similar to what is shown in Vú Tú Nam's short story discussed above, Ma Văn Kháng emphasizes that people have a responsibility for their own lives as well as for society, and family is the fundamental unit of society. However, Vietnamese people, as Ma Văn Kháng tries to point out in the novel, are so used to living with political affairs and a collective life that they do not know how to manage a private life. The dark-sidedness of human beings such as jealousy or selfishness, which might have been temporarily repressed when everybody in society was committed to national salvation, began to appear again in post-war society. These problems are illustrated in Ma Văn Kháng's celebrated novel.

This novel also marks a change in Ma Văn Kháng's writing style. That is, he shifted his interest from the problems of rural people to a middle-class urban family, which is uncommon in his previous works focusing on ethnic people in mountainous areas. Mùa Lá Rụng trong Vườn (The Season of Leaves Falling in the Garden) shows the decline of the traditional family and old values during the transitional period from the end of the struggle to the epoch of peace. In the story, Mr. Bằng, a retired high-ranking official, tried to be severe with his children because he wanted to preserve the traditional family. The family members were supposed to be successful and dignified. In the last days of his life, he was humiliated by the fact that Cừ, one of his children, left the country and emigrated to Canada. Before he committed suicide, Cừ sent a letter to his father and explained what made him make that decision. The letter revealed that he left the country because he would never be able to reach the standard set by his own family and society's expectations. Cừ was denounced when he complained about the hunger and hardship he had to endure while fighting at the front. He became disillusioned and hopeless in a society that demanded that people involuntarily sacrifice everything for the collective and keep personal suffering to themselves. As implied by Ma Văn Kháng, one cannot make a quick judgment whether people are good or bad only by looking at social standards or morality because life is too complicated to be framed by political and social criteria.

Mr. Bằng dies before he has to witness the tragedy of Đông, the eldest son in the family. Đông believed that he had a right to take a rest and enjoy himself after the long period of serving the country on the battlefield whereas his wife, Lý, wanted to be materially superior to other people. Dissatisfied by her husband's passivity and lack of ambition, she decided to leave him and lived with another man in Ho Chi Minh City. Lý's behaviour was criticised by family members. It seems that only Luận, a younger brother of Động, had sympathy for his sister-in-law. For him, Lý was actually a victim of her own attitude to life as well as the materialistic post-war society. As Luận commented:

This event is not simply an act of adultery. It is evident that Lý made a mistake. But, is it true that Động and nobody in the family do not take part in this mistake? The nation, after thirty years of fighting against enemies, is in the 
process of restoration with deprivation and hardship. The nation has never been so highly heroic and glorifying like this before. Yet, life has never been so difficult and excited by materialistic values and selfishness like this either.

(Ma Văn Kháng 1985: 245)

The two stories discussed above show that literature is not only to serve political purposes, but literature is to portray every life problem such as how to earn a living and family affairs. This is also an attempt to disengage politics from literature, and pay more attention to individuals' struggle in everyday life.

\section{Alarming reality and unpleasant truth}

The works written in the post-1975 period reveal the dark side of society, especially corruption and the deterioration of morality among cadres. Two novels by Nguyễn Mạnh Tuấn, Sống Truớc Biển (Standing before the Sea), written in 1982, and Cù Lao Tràm (The Tràm Island), written in 1985, gained considerable attention from readers. Seen through these two novels, there is no doubt that the author still has strong faith in socialism. However, the author attempts to speak out about the unpleasant reality that not many people at that time dared to mention, or simply pretended not to know about. In these two novels, Nguyễn Mạnh Tuấn reveals that bureaucracy, corruption, and materialism are problems that exist in this socialist country, too.

The novel Đưng Truớc Biển (Standing before the Sea) shows that life in the postwar society is complicated, and it can be even more complicated than during the war. Developing the economy and building a socialist society are also difficult tasks. Thus, those who take charge of building a better society for the masses need to stand their ground firmly; otherwise, they could be tempted by personal benefit or materialistic values.

In Cù Lao Tràm (The Tràm Island), the author turns his attention to the peasants in the South. The belief in the vital role of the masses in building socialism is still expressed in this novel. In the story, the peasants are characterized as moralistic, industrious and loyal to the party. However, they begin to rebel against local authorities who abuse their power to exploit people for personal advantages. Nam Trà, a party member in the story, tries very hard to fight for her idealistic goal, to build a socialist society and bring a better life to everybody. However, she feels isolated among her colleagues who give up their socialist morality.

In terms of theme and style of writing, Nguyễn Mạnh Tuấn's famous novels do not contribute much to the development of literature in the post-1975 period. However, social problems sincerely shown in his novels helped warn readers about the dark side of society and urgent issues needed to be resolved. It is like what Nguyễn Minh Châu said about the role of literature in the note written on his deathbed, '...therefore, it is necessary to have writers in this world in order that they awaken and warn the human beings of disasters. ${ }^{10}$

\footnotetext{
${ }^{10}$ Nguyễn Minh Châu wrote this note when he stayed in hospital a few days before he passed away. There are six pages in all (Tôn Phương Lan 1994: 139).
} 
In the early 1980s, Nguyễn Minh Châu was concerned about urgent problems caused by economic hardship although it seems that he hesitated to continue the vigorous polemics on freedom in literature and creativity he initiated in 1979. The novel Nhũng Người Đi Tù Trong Rùng Ra (Many People who Come from the Forest) [1982] shows that Nguyễn Minh Châu was concerned about the economic crisis and social development in the post-war period. The main purpose of this novel is to strengthen the morality of people in the post-war time and to support government plans to turn the whole country, North and South, into a complete Socialist society. This novel gives a panoramic view of Vietnam in 1980s. It covers the pictures of economic crisis that affected the life of each individual, the criticism of the Chinese people in Vietnam, which is the impact of the Sino-Vietnamese conflict in 1979, and the influx of emigrants abroad. The economic difficulties, poverty and famine of the post-war period are clearly portrayed. As shown in the story, some families had only rice and salt for their meals. Nguyễn Minh Châu accepted that there was something wrong with the economic development and probably it was the failure of the Socialist system of collectivization. Yet, he still had strong faith in Socialism and believed that the morality of the Communist cadres would be able to solve this crisis. It is clearly shown in the novel that some officials and party members began to doubt Socialism as a model of development. The war heroes in the story realized for the first time that the economic hardship of the post-war era was much more difficult than fighting on the battlefield:

...Hiển has never thought that to earn a living is a difficult task, extremely difficult. He has just realized that what he used to think-that it was very simple, such as catching fish on the sea or growing a grain of rice in the fields, is not simple, not at all!

(Nguyễn Minh Châu 1982: 75)

\section{The conflict between the collective and the individual}

Through the long history of war and foreign invasion, the criterion used for the evaluation and judgement of people and literary works was 'collective responsibility.' In wartime, a person could be regarded as good and respectable only when devoting himself or herself altruistically to the nation. In literary works, the characters are represented as part of the group. Individuals are allowed to appear in literary works only when they represent an ideal member of the group. It was also generally believed that any good literary work must underline collectivism and include social and political consciousness. However, the concept of collective and socio-political commitment in literature became less important in the post-war period when writers began to pay more attention to the inner dilemmas of individuals, their daily problems and their relationships with others in society.

Changes in the socio-political context since the late 1980s allowed Vietnamese scholars, writers and critics to rethink the issue of collectivism and individualism. For instance, the famous writer Nguyễn Huy Thiệp expresses his view on this subject as follows: 'Human beings have to think about many things, not only political affairs. Literature must pay attention to human life and reflect the complexity of 
life. ${ }^{11}$ Likewise, in the controversial article entitled "Văn Hoc và Chính Trị" (Literature and Politics), Lê Ngọc Trà proposes that literature's function is to explore and depict human life, and reflect the destiny of each individual. Compared to political ideology, stories about everyday life, such as love stories, might be considered 'nonsensical, weak or romantic.' Lê Ngọc Trà agrees that 'Politics is something very important in society', but strongly argues that 'life is still more important than politics'(Lê Ngọc Trà 1987: 10). This issue is also discussed in Hoàng Ngọc Hiến's essay 'Chủ Nghĩa Hiện Thực và Chủ Nghĩa Nhân Đạo' (Realism and Humanism). In it, he suggests that individualism should be better emphasized. As he argues:

National liberation is a sprout of the liberation of mankind. Our nation is already liberated, but individuals are still tied by visible and invisible threads. Socialist humanism respects the liberation of each individual as well as of mankind.

(Hoàng Ngọc Hiến 1997: 20)

It is also remarkable that writers begin to use the form of tragedy instead of epic. In Socialist Realist literature, characters are always optimistic and enthusiastic about the future of the society. They can be depicted as individuals, but these individuals must represent the good qualities of the people that the state would like to see. Therefore, the idea of selflessness, industriousness and heroism

11 Quoted from the report no.16 in the report of the Conference 'Những Vấn Đề Thời Sự về Văn Học' (Many Current Problems of Literature) by Teacher Training College, Hanoi, published in April 1989. Page unknown. are glorified whereas weakness is not allowed in literary works. Thus, the shift away from epic toward tragedy is closely related to the changing values of the postwar society from collectivism to individualism. Tillyard (1958) explains the nature of the epic form as follows:

What most makes the epic kind is a communal or choric quality. The epic writer must express the feelings of a large group of people living in his own time. True, all personal feelings take on some from the general temper of an age. But, granted that, there are feelings that appear to be the unique concern of the individual and feelings which he knows, consciously or not, are shared by a great body of his fellows. That sharing gives those feelings a peculiar force and favor, and it forms the psychological ground and the justification of the epic kind.

(Tillyard 1958: 3)

In contrast with the epic form that underlines collective values and feelings, tragedy has a special character to highlight individual desires. As Tillyard puts it:

Tragedy cannot take some imprint of its age, but its nature is to be timeless. It deals with the recurrent human passions and, aiming at great simplicity, presents their bare elements, with Not too much local circumstantiation. It teaches not what it is like to be alive at a certain time but what it is like to be a human being.

(Tillyard 1958: 15) 
Therefore, the change in the use of literary form in the post-war period shows the decline of Socialist Realism, as mentioned earlier in this study, which usually focuses on reflecting the positive side of society and success more than exposing negative things or discussing failure. In contrast, tragedy is a literary form that underlines the flaws of the main characters. In the famous novel: Thời Xa Vắng (A Time Far Past) [1986], the author, Lê Lưu, illustrates the shift from epic to tragedy and the transfer of emphasis from collectivism to individualism. Although Lê Lưu's novel touches upon many social concerns at that time, the discussion below lies specifically on how the story reflects the conflict between collectivism and individualism in Vietnamese society.

The history of a Vietnamese peasant is thoroughly narrated through the life of Giang Ming Sài, the protagonist of the novel. The author portrays what a Vietnamese peasant has had to go through, from the feudal period to the socialist transformation and the post-war era. Also, this is a good example of a literary work that focuses on an individual life rather than historical events. The story starts in 1954 when the French are defeated and ends in 1984, two years before the Renovation policy is announced. At the age of ten, Sài was already married. The marriage was arranged by his parents, which was quite common for traditional families in Vietnam. Sài does not love his wife, Tuyết, but he cannot leave her because it would have an effect on the reputation of his family, particularly as his father is a Confucian scholar, and his uncle and brother are Communist cadres. $\mathrm{He}$ is even more irritated by his wife when he falls in love with Hương, his classmate. Disappointed that his family will not allow him to divorce his wife and be with the woman he loves, Sài decides to escape from frustration by joining the army:

He left as if sneaking away, as if fleeing from yesterday, today and tomorrow, as if he were smugly satisfied with his "courageous" decision to endure in silence.

(Lê Lưu 1997: 50)

When his superiors find out that Sài does not love his wife and is obsessed with another woman, they are unhappy. They use the concept of class to analyze Sài's relationship with his wife, and conclude that Sài shows indifference towards his wife because he is influenced by 'bourgeois thinking.' They assume that he looks down on his wife because she is an ordinary peasant, and that he longs for Hương because she is more refined and educated. His superiors set the condition that he will be allowed to join the Party only when he loves his wife. However, he is not allowed to become a party member because his wife's father has associated with the French. Furthermore, Hương decides to marry someone else after she hears that his wife is pregnant. Finally, his family and superiors allow him to divorce. He once complains to Đỗ Mạnh, described in the novel as a liberal-minded political officer, that his personal life might not have been so full of suffering if his family and superiors had not intervened. But his former commander argues that Sài cannot blame anybody but himself for his unhappiness. As Đỗ Mạnh explains to Sài:

Your own life is nothing but the well-worn life of a hired hand. Eat whatever food is given, do whatever job is assigned, always anxiously waiting for the boss's orders, never having the nerve to decide anything on your own. 
That's okay for a little child. But after your graduation, you became a citizen, a combatant, why wouldn't you take responsibility for your own life? Why couldn't you openly say, 'This is a coercive situation. My feelings will not allow me to live with that woman. If you insist on browbeating me into it, I stand ready to give up everything I have. Even if I have to return home as a (plough) man, I will do it to be able to live the kind of life I want.' But, you didn't say this. Instead, like a man tied with ropes, you dared not move, you only waited anxiously, hoping against hope.

(Lê Lưu 1997: 140)

When the war is over, Sài works in Hanoi. Free from familial and political ties, he expects to pursue a happy life and decide things for himself. He gets married for a second time to Châu, a city girl. This marriage is also unsuccessful and ends with divorce due to the differences between the two of them. Moreover, Châu hurriedly marries Sài, not because she is in love with him, but because she is secretly pregnant by a married man. After his second marriage fails, Sài returns to his home village and becomes the chairman of a collective farm.

Towards the end of the story, it is seen that the quest for individual happiness in Tho $i$ Xa Vắng (A Time Far Past) by Lê Lưu does not challenge the concept of collectivism directly, but rather calls for the recognition of the existence of individuals in society. The novel reveals the tension between individual desires and collective duties. While trying to complete their tasks and responsibilities to the nation, individuals feel, at the same time, estranged and exhausted.

\section{Conclusion}

Social conditions in the post-war period allowed Vietnamese intellectuals and writers to challenge Socialist Realism, which was the state's guideline for writing. However, one must bear in mind that this is not an attempt to overthrow the Communist government. It is not a political conflict, but it is a conflict of ideas aimed at achieving individual freedom of expression as well as an attempt to disengage literature from state guidance and control. As seen through the development of Vietnamese society, literature has played an important role in political struggles, especially in terms of mobilizing the masses to fight against foreign troops and build a Socialist state. Nevertheless, Vietnamese poets, novelists and short story writers argued that their tasks should be different when the war was over. As seen in the novels and short stories written between 1975 and 1986, Vietnamese literature shows a sensitivity towards the historical and social changes in the post-war society by focusing on problems of everyday life that people have to face in the new society. The elements of Socialist Realism, which were very functional during the wartime, are no longer suitable for the post-war life and literature.

\section{References}

\section{English}

Borland, Harriet. 1950. Soviet Literary Theory and Practice during the First Five - Year Plan, 1928 - 1932. New York: King's Crown Press, Columbia University. 
Brown, Edward J. 1982. Russian

Literature since the Revolution. Cambridge and London: Harvard University Press.

Hue Tam Ho Tai. 1982. 'Literature for the People: From Soviet Policies to Vietnamese Polemics' in Truong Buu Lam (ed.). Borrowings and adaptations in Vietnamese Culture. Southeast Asia Paper No. 25. Centre for Asian and Pacific Studies, University of Hawaii at Manoa, pp. 63-83.

Lenin, V.I. 1970. 'Party Organisation and Party Literature' in On Literature and Art. Moscow: Progress Publishers.

Mao Tse-Tung. 1967. On Literature and Art. Peking: Foreign Languages Press.

Robin, Regine. 1977. Socialist Realism: An Impossible Aesthetic. Translated by Catharine Porter. California: Standford University Press.

Scott, H. G. 1977. Soviet Writers' Congress 1934: The Debate on Socialist Realism and Modernism in the Soviet Union by Maxim Gorky, Karl Radek, Nikolai Bukharin, Andrey Zhdanov and Others. London: Lawrence and Wishart.

Struve, Gleb. 1946. 25 Years of Soviet Russian Literature (1918-1943). London: George Routledge \& Sons.

Trường Chinh. 1994. Selected writings. Hanoi: foreign Languages Publishing House.

Tillyard, E.M. W. 1958. The Epic Strain in the English Novel. London: Chatto \& Windus.

\section{Vietnamese}

Hoàng Ngọc Hiến. 1979. "Về một đặc điểm của văn học và nghệ thuật ở ta trong giai đoạn vừa qua". Văn Nghệ, số 23 .

. 1997. 'Chủ Nghĩa

Hiện Thực và Chủ Nghĩa Nhân Đạo’ (Realism and Humanism) in Văn Học và Hoc Văn (Literature and Literary Studies). Hanoi: NXB Văn Học.

Hồ Chí Minh. 1996. 'Nâng cao đạo đức cách mạng, sạch chủ nghĩa cá nhân' (To Increase Morality of Revolution, To Wipe Out Individualism' in Hồ Chí Minh: Collected Works. Vol. 11. Hanoi: NXB Chính Trị Quốc Gia.

Lê Lưu. 1997. A Time far Past. Translated by Ngo Vinh Hai, Nguyen Ba Chung, Kevin Bowen and David Hunt. Boston: University of Massachusetts Press Amherst.

Lê Ngọc Trà. 1987. 'Văn Học và Chính Trị' (Literature and Politics) in Văn Nghệ, no. 51-52 (19-12-1987).

Ma Văn Kháng. 1985. Mùa Lá Rụng trong Vuoòn (The Season of Leaves Falling in the Garden). Hanoi: NXB Phụ Nữ.

Nguyễn Đình Thi. 1998. 'Nhận Đường' (Recognised the Path) in Mã Giang Lân. Văn hoc Việt Nam 1945-1954 (Vietnamese Literature 1945-1954). Hanoi: NXB Giáo Dục.

Nguyễn Minh Châu. 1978. 'Viết về Chiến Tranh' (Writing about War) in Văn Nghệ Quân Đội, no. 11.

Nguyễn Minh Châu. 1982. Nhũng Người Đi Tù Trong Rùng Ra (People who 
Come from the Forest). Hanoi: NXB Quân Đội Nhân Dân.
Viết Văn' (Literary Notes) in Tôn Phương Lan (ed.) Trang Giấy trước Đèn. Hanoi: NXB Khoa Học Xã Hội.

$$
\text { . 1994. 'Bên lề tiểu }
$$

thuyết' (About Novel) in Tôn Phương Lan (ed.). Trang Giấy

truoóc Đèn. Hanoi: NXB Khoa

Học Xã Hội.

Tôn Phưong Lan (ed.). 1994. Trang Giấy Trước Đèn. Hanoi: NXB Khoa Học Xã Hội.

Trường Chinh. 1960. 'Đề Cương Văn Hoá Việt Nam 1943' (Vietnamese Cultural Theses 1943) in Về sụ lãnh đạo của đảng trên mặt trận tu tuởng và văn hoá 1930-1945 (About the Leadership of the Party on Ideology and Culture 1930-1945). Hanoi: NXB Sự thật. Nhũng Vấn Đề Thời Sụ về Văn Học. (Many Current Problems of Literature) by Teacher Training College, Hanoi, published in April 1989.

Văn Tân và Nguyễn Hồng Phong. 1957. Chống quan điểm phi vô sản về Văn Nghệ và Chính Trị (Fighting against Non- proletariat Attitude in Art and politics). Hanoi, NXB Sự Thật.

Vũ Tú Nam. 1985. 'Sống với Thời Gian Hai Chiều' (Living in Two Sides of Time) in Truyện Ngắn Việt Nam 1945 1985 (Vietnamese Short Stories during 1945 - 1985). Hanoi: NXB Giáo Dục. 